\title{
Optimal Land Use Classification for Iraq Cities
}

\author{
Nabil T. Ismael, Ali Awda Mohammed, Samaan Majeed Yas \\ Department of Architectiral Engineering, College of Engineering, University of Diyala \\ nabiltaha2001@gmail.com,nabiltaha001@engineering.uodiyala.edu.iq
}

\begin{abstract}
The classification of land uses in the city is an essential element for the organization and distribution of land uses when it is preparing and updating master plans for cities. The land uses in each country are divided into single, secondary, hierarchical or other classifications according to the planning requirements for land uses in the country.

The problem of research is that most land-use classifications in Iraqi cities lack a uniform and convergent classification of land uses which they depend for updating or preparing the master plans, so, the studying and analyzing the classification of land uses for seven Iraqi cities, we note that there is no uniform and convergent classification, and there isn't overlap and complementarity of land uses for the existing and future of land use classification in these cities.
\end{abstract}

The aim of the research is to prepare a proposal for the classification of land uses for Iraqi cities as a reference and guide when the preparation and updating of the master plans for Iraqi cities.

One of the most important research conclusions is unclear classification of the land uses in Iraqi cities either primary or secondary classification but there is a different classification of each city according to the existing of land use, and its adoption in whole or near total for future land uses.

The research proposed to classify land uses into seven major classifications, including residential, economic, mixed, public services, recreational, infrastructure and other land uses, these major land uses have been classified into 19 secondary classifications and more than 60 land use in detail.

Keywords: Land Use Classification, Iraq Cities, Master Plans, Primary Land Use, Secondary Land Use, Detailed Classification.

Paper History: (Received :31-1-2019;Accepted:3-3-2019)

\section{Introduction}

City planning should be based on the principle of sustainability, in order to achieve sustainable urban development [1]. Estimating the amount and form of all Iraq's urban development is a serious need. In addition, because of the absence of suitable land use planning and the measures for sustainable expansion, unplanned urban growth has been generating simple urban consequences [2].
The improvement and integration of land use in cities requires knowledge of their classification clearly and carefully in order to achieve well-being and improve the quality of life in the city. It needs for optimal classification of land uses in Iraqi cities which is the result of a difference between the classification of land uses from one city to another, despite the similarity of all social, economic, demographic and physical characteristics, as well as the absence of a clear methodology for collecting and integrating convergent land uses in terms of functionality and use.

The preparation of an optimal classification of land uses for Iraqi cities require knowledge of the existing of the land use classification for a group of Iraqi cities to develop a future vision for an appropriate classification that is compatible with the zeitgeist capable of solving urban problems in Iraqi cities and according to the planning of land uses in Iraq.

\section{Concept of Land Use Classification}

The issue of land use classification is a truly crosscutting one. The function of such a land uses classification to like many currently which uses at the global level is mainly to serve as a correlation system through which land use classes from existing national systems could be correlated and global land use databases can be continuously maintained and developed. It is not realistic to expect that, through this proposed land use classification, countries will be asked to change their existing national classification systems that have been developed and applied in response to local decisionmaking needs [3].

"Land Use Planning" is a multi-dimensional discipline which derives from the complex inter-relationship of physical planning (space); ecology (existing systems on the land); and human systems of land use (demographics, economic development, industrial, commercial, residential and societal needs, political systems, particularly at subFederal level, availability of funding, and law) [4].

The practice of land use planning is supported by theoretically based but practically oriented concepts such as "Euclidian Zoning" (separation of uses of land, particularly separating residential from commercial/industrial uses) [5]; "New Urbanism" (mixed residential/ commercial uses, in walkable neighborhoods); "Smart Growth" (increased urban density, infill development on "brownfields" and the protection of exurban "green fields" for agriculture and open space) [6]; and "Sustainable Development" (attempt to protect and 
preserve local employment opportunities, quality of life, natural resources, and the environment) [7].

There are a series of four types of classification systems that lie along a continuum from basic and simple to more sophisticated and complex, it includes: categorical, hierarchical, multidimensional, and semantic [8].

The aim of a land use classification is to establish a national system for naming and defining groups of land use. Elements of such a system include [9]:

- detailed land uses.

- definitions of land uses.

- hierarchy or grouping of land uses.

- a methodology of deriving these land uses.

- a set of symbols to report on or map the land uses.

In UK, the National Land Use Database (NLUD) has developed as a framework for land-use classification, with the latest version known as NLUD version 4.4. The NLUD is a hierarchical classification with 13 order names and 41 group names. The classification builds on previous landuse classifications by addressing their shortcomings and considers current policy priorities [10]. The specific aims of the classification are to establish a national system for naming and defining groups of land use and land-cover features, to provide a nationally consistent basis for identifying, recording, reporting land use and land cover, and to be used as a standard classification involved in routine collection of land use and land-cover data [11].

\section{Land Use Classification in Iraq Cities}

The research addresses of the classification for existing and future land uses for a group of major cities in Iraq, it is showing how classification and types of land uses.

\section{1) Basra City}

Table (1) shows the land uses of Basra city (2009), we note a primary and secondary classification of most land uses. Table 3 shows the future land uses of Basra city (2030) we note that all land uses are primary classification and don't include except residential land use. Tables (1) and (2) show the following:

- The classification of existing and future residential land use is different, as it has classified according to the type of housing in 2009 (single and multi-storey), while it was classified according to density in 2030. This indicates the need to adopt population densities in the city.

- Commercial land use has been combined with the mixed land use for existing and future land uses, classified in 2009 into commercial, hotels and tourism, while some classifications add hotels into residential land use, as well as the addition of business use in 2030, which is separate from commercial land use.
- Existing and future land uses of industrial, educational and health hasn't been classified into secondary classifications.

- The land use in 2009 for community services (mosques and religious services and social facilities), cultural and recreational (heritage, facilities for entertainment and sports and recreation) and open spaces, agricultural and orchards (open public place, agricultural and palm orchards), have been classified into secondary groups. In 2030, these land uses have integrated into non-interrelated and non-integrated main land uses between them (mosques and cultural services, recreation and special uses and open areas, parks and city edges).

- A primary classification of transport and infrastructure has classified with secondary classification by different modes of transport in 2009, while in 2030 it has classified as only roads and highways with neglect of the other modes of transport such as railways, airports and seaports.

- The lack of clarity of the classification of the existing and future of the land use for Basra city, and the overlap between them and the lack of suitability in terms of classification.

\section{2) Amarah City}

Table (3) shows the classification of land uses for Amara city in 2007 and 2030, there is a primary classification of land uses only based on the combination of more than the land use and its reduction in one primary classification. As follows:

- Non-classification of residential land use by density or type of housing, which doesn't achieve diversity and consider family income and the cultural level of the family. - The existence of mixed land use individually and independently from commercial use, this is a positive indicator of land use classification, which is a tool for achieving sustainability.

- Integrating commercial land use with institutional land use: this is a contradiction between the two land uses due to the lack of suitability and complementarity of both land uses.

- Integrating warehouses with industrial land use: Warehouses represent places to collect goods and not limited to industrial land use only but can be added to commercial land use as well.

- Integrating security land uses with the administration land use: Security use (police, civil defense, security facilities) which is a part of administration land use, while military land use represents other land uses that usually occur outside the cities.

- Integrating cultural land use with tourism land use: Cultural land use is a variety of different places, sometimes within tourist or recreational areas.

- Integrating recreational, open space, sports and youth, and cemeteries land uses: These land uses represent 
convergence and complementarity with each other, except for cemeteries that are part of religious land use.

- Public services: The classification of land uses don't show what public services have in the Amara city, which have included many land uses that have included in other land uses.

- The integration of land uses hasn't compatible and inconsistent in Amara city.

\section{3) Hillah City}

Table (4) shows the classification of land uses for Hillah city in 2006 and 2030, there is a primary classification of land uses only has based on the combination of more than the land use and its reduction in one primary classification. As follows:

- Land uses in Hillah city include common land uses such as residential, industrial, educational, health and religious independently and separately.

- Land use in Hillah city is characterized by mixed land use independently and this is a sustainable indicator of land use.

- Integration of a set of attractive and convergent land uses, such as cultural with tourism land use together and sports and youth with recreation and open space as one integrated land use, or incompatible land uses together such as commercial with governmental land use and administrative with security land use.

- The transport use has focused only on transport infrastructures, which are roads without mentioning other modes of transport such as shipping, air and various transport stations.

- The table shows the absence of public and service land uses independently but has distributed to the rest of the land uses, for example government with commercial and administrative with the security as well as the existence of the infrastructure land use independently.

- The classification of land uses in Hillah city lacks an appropriate and comparable distribution of the land uses, which leads to an imbalance by classifying the land use and reducing the area allocated to the individual in the city.

\section{4) Ramadi City}

Table (5) shows the classification of land uses for Ramadi city in 2009 and 2033, the existence of a primary classification based on the combination of more than one land use and it summarized in one main classification, as well as differences for some land uses between 2009 and 2033, as follows:

- The land uses of Ramadi city include common land uses such as residential, industrial, educational, health and religious independently and separately.

- Integration of commercial land use and mixed land use with some, public and service land uses together, as well as integration of stations with railway tracks and roads and transportation networks.

- Separation of land uses from the land uses of converging and interrelated with each other individually such as recreational, green areas, water areas, cemeteries, military, private areas and oil stores and warehouses. Other land uses have separated in 2033, such as cultural, tourism investment, car Showrooms and international transport garage.

- The use of administrative centers, city center, district center, quarter center and neighborhood center have added to the land uses in Ramadi city in 2033.

- The classification of land uses in Ramadi city is characterized by the multiplicity of individual classifications and the fragmentation of land uses converging and compatible with each other and this leads to the dispersion of land uses in the city.

\section{5) Al Muqdadiya City}

Table (5) shows the classification of land uses for $\mathrm{Al}$ Muqdadiya city in 2010 and 2030, the existence of a primary classification has based on the combination of more than one land use and it summarized in one main classification, as well as differences for some land uses between 2010 and 2030, as follows:

- Land uses of Al Muqdadiya include common land uses such as residential, commercial, industrial, educational, health and religious independently and separately, as well as land uses such as infrastructure, security, heritage, culture, transport and agricultural land.

- Integrated land uses are integrated with each other such as government administrative use with public services and leisure use with tourism as well as sport with young people and open areas with green areas.

- The convergent and integrated land uses have been combined such as government administrative land use with public services and recreational use with tourism as well as sport with young and open space with green areas.

- The land use of security, heritage and infrastructures have appeared in the classification of land uses in 2010 and disappear in 2030.

- The emergence of public services, energy and other land uses as future land uses in 2030.

- The land uses in Muqdadiya city is characterized by a combination of a set of single land uses with dual land uses integrated with each other. There is a correlation between the land uses converging and integrated with each other but separated and fragmented into a single land use.

\section{6) Balad City}

Table (7) shows the classification of land uses for Balad city in 2009 and 2035, the existence of a primary classification has based on the combination of more than one land use and it summarized in one main classification, 
as well as differences for some land uses between 2009 and 2035, as follows:

- Balad city is characterized as an agricultural city and thus has been affected by the classification of land uses in the city. We note that the land uses didn't previously appear as technical infrastructure and transport infrastructure.

- Most of the land uses in Balad city are of a recreational nature (agricultural and water) such as public places, agricultural areas, parks, lakes, water areas, landscape, gardens, orchards and natural areas.

- The city has a traditional classification of land uses only for residential and industrial land use by adding production with it.

- The land use of public services, parks, lakes and landscape has appeared in 2009 and disappear in 2035, while the place of these land uses emerged land use of gardens, orchards and natural areas in 2035.

- Shows that the nature and function of the city has an impact on the classification of land uses and therefore land uses are different from the land uses of other cities.

\section{7) Karbala City}

Table (8) shows the classification of land uses for Karbala city in 2007 and 2030, the existence of a primary classification based on the combination of more than one land use and it summarized in one main classification, as well as differences for some land uses between 2007 and 2030, as follows:

- The classification of residential land use of Karbala city is characterized by the inclusion of streets within the residential area as well as green areas.

- The classification of the land uses of Karbala city includes industrial and commercial land uses as well as warehouses which is considered an important land use in the city as a center for the export of dates outside Iraq.

- In 2007, public services land use included educational, health, religious and cemeteries as individual land uses, while in 2030 they all became the single land use which is public services.

- The rest of the land uses have classified in 2007 and 2030 into the public facilities of both the green areas and parking, as well as the transport and roads, agricultural and vacant areas.

- The classification of the land uses of Karbala city shows a clear difference from the rest of the land uses for Iraqi cities as a result of the city's religious function (holy shrines) and agricultural (dates orchards), so the land uses of reduced and shortened has appeared, and to merge the land uses with one land use only, such as public services.

\section{Optimal Land Use Classification for Iraq Cities}

The research proposes the preparation of a classification of land uses for Iraqi cities that can be relied upon when preparing or updating the master plans of cities. The proposed classification is based on the division of land uses into three classifications (table 9):

1) Primary Classification: They are classified into seven main categories: residential and economic (business), mixed land use, public services, recreational, infrastructure and other land uses, which are the basic land uses of cities. 2) Secondary Classification: The primary classification has been divided into a secondary classification, to divide the land uses by sectors and activities in the city, as follows:

- Residential land use: It has divided according to the pattern of distribution for housing units. It has divided into the pattern of single housing units as horizontal expansion of the city as well as the division into the pattern of vertical expansion (multi-story building) for housing units.

- Economic land use: It has divided by type of activity, as it has divided into commercial, industrial and investment activity as land uses which employs the largest number of city's population in various economic activities and events.

- Mixed land use: It has divided according to the hierarchy of distribution for service and residential centers in the city, they have divided into mixed land use in the city center, district center, quarter center and neighborhood center.

- Public Service land use: It is divided according to the side and type of service provided to the citizens. It is divided into government services that provide administrative and organizational services to citizens, and security services that guarantee and maintain the security of citizens and provided by the government agencies, as well as community services that improve and develop citizens.

- The recreational and entertainment land use: It has divided according to the built-up and non-built-up area. The non-built-up area has divided into agricultural and water areas. The built-up areas have divided into recreational facilities that included the buildings and open spaces.

- Infrastructure: It was divided according to its percentage and the visible or invisible of its buildings in the city, as it was divided into two categories. The first is the transport, which is visible and not hidden, which represents a large percentage of land use in the city, and the second is the infrastructure facilities which are hidden and invisible except for some of its buildings.

- Other land uses: They have divided according to the built-up or non-built-up areas, they have divided into vacant areas that don't contain buildings, and special areas 
containing buildings with certain land uses not previously mentioned.

3) Detailed Classification: The land uses are categorized in detail for each secondary classification by density and components of each secondary classification in terms of convergence and suitability of the land uses, as follows:

- Residential land use: It has classified according to the population density, it has divided into low, medium and high density in order to achieve diversity in housing and distribution according to the desire and income of families in the city.

- Commercial land use: It has divided by trade level and classified into wholesale and retail trade as well as the addition of commercial stores and warehouses.

- Industrial land use: It has divided according to manufacturing levels in the city, divided into light, medium and heavy industries, as well as service industries such as maintenance of cars and industrial warehouses.

- Investment land use: After 2003 the importance of the private sector increased and investment increased so it requires the addition of land use for investment purposes in all sectors, including hotels, restaurants, café, companies, offices, car fairs, banking sector and investment sites.

- Mixed land uses in the city center and district centers: It has included the integration of land uses includes government services, economic use and multi-storey housing to integrate them.

- Mixed land uses in the quarter center and neighborhood center: It has included the integration of land uses includes recreational with economic land uses to improve the housing environment, provide work and recreation and proximity to housing.

- Government services: It includes all services provided to citizens by the government in ministries, institutions and departments for all sectors and life activities.

- Security services: It includes military sites with its various facilities, police sites with other security services associated with them, as well as service facilities that are linked to security services such as fire department and others.

- Community services: Its works to develop and improve the educational, health and psychological level of the human being and it include educational, health, and places of worship and cemeteries.
- Agricultural areas: It includes all open areas of green nature, which are of environmental, health, psychological, economic and recreational importance to the community, it includes agricultural areas, parks, landscape, natural areas, green squares, gardens, and orchards.

- Water areas: They are of great importance in improving the microclimate and providing a suitable and appropriate environment for humans to entertainment and improve the psychological condition of the human being, it includes all water areas, lakes, waterways (rivers, streams, etc.) and fountain

- Recreational facilities: It includes all the built-up and open areas that provide rest and recreation to the human being and work to improve the health, psychological, cultural, recreational and civilizational level of the community, it includes heritage and archaeological areas, conservation areas, youth and sports facilities, cultural facilities and resorts, clubs and entertainment halls.

- Transportation: It is the focal point of land use, which is important in bringing together the various activities in the city. It includes roads of all kinds, highways, local and international transport stations, airports, railway stations and tracks, metro, monorail, parking, cycling and sustainable transport modes.

- Infrastructure facilities: It represents all the services it provides to citizens whether governmental or private sector, that provide well-being and a better standard of living for the community and measured through which the well-being and development of the state and society. It includes water, electricity, communications, sanitation, municipal services, fuel, etc. and includes its buildings, routes and warehouses.

- Vacant areas: It represents the vacant places and areas of the city are due to their inadequacy and appropriateness for their allocation to appropriate land uses and their nondevelopment. It includes derelict, unused and undeveloped land, lands dedicated to future development, protected landscapes, buffer zones, unmodified land and not applicable for development.

- Special areas: The classification of land uses in the city requires a classification of special uses that don't belong to a particular classification and aren't continuously and permanently available, it includes land uses that haven't prior classification, slums and buffer facilities.

Table 1 Basra Land Use 2009 [12]

\begin{tabular}{|c|c|c|}
\hline & Key Land Use & Details \\
\hline \multirow{3}{*}{1} & \multirow{3}{*}{ Residential } & Residential \\
\cline { 3 - 3 } & & Residential multistory building \\
\cline { 3 - 3 } 2 & Commercial/Mix use & Villas \\
\cline { 3 - 3 } & Industrial function & Commercial \\
\hline 3 & Educational & Industrial \\
\hline 4 & Public and civic services & Educational services \\
\hline 5 & & Civic \\
\hline
\end{tabular}




\begin{tabular}{|c|c|c|}
\hline & & Public services \\
\hline 6 & Healthy services & \\
\hline \multirow{2}{*}{7} & \multirow{2}{*}{ Community services } & Mosques and religious services \\
\hline & & Social facilities \\
\hline \multirow{3}{*}{8} & \multirow{3}{*}{ Cultural and recreational } & Heritage \\
\hline & & Facilities for entertainment \\
\hline & & Sports and recreation \\
\hline \multirow{3}{*}{9} & \multirow{3}{*}{$\begin{array}{c}\text { Open space, agricultural and palm } \\
\text { orchards }\end{array}$} & Open public place \\
\hline & & Agricultural \\
\hline & & Palm orchards \\
\hline \multirow{5}{*}{10} & \multirow{5}{*}{$\begin{array}{c}\text { Infrastructure for Public Services and } \\
\text { Transport }\end{array}$} & Infrastructure \\
\hline & & Facilities for ports and river transportation \\
\hline & & Airport \\
\hline & & Railway Station \\
\hline & & Parking \\
\hline 11 & Land designated for future development & \\
\hline \multirow{2}{*}{12} & \multirow{2}{*}{ Others land use } & Cemetery \\
\hline & & Military \\
\hline
\end{tabular}

Table 2 Basra Land Use 2030 [13]

\begin{tabular}{|c|c|c|}
\hline \\
\hline & Key Land Use & Details \\
\hline \multirow{5}{*}{1} & \multirow{5}{*}{ Residential } & Low density \\
\hline & & Medium Density \\
\hline & & High density \\
\hline & & Residential areas of mixed uses \\
\hline & & Villas \\
\hline 2 & Commercial / Mix use & \\
\hline 3 & Public and civic services & \\
\hline 4 & $\begin{array}{c}\text { Culture, rest and relaxation, the land uses of } \\
\text { privacy }\end{array}$ & \\
\hline 5 & Mosques and cultural services & \\
\hline 6 & Educational & \\
\hline 7 & Healthy services & \\
\hline 8 & Open Spaces / Buffer Areas / parks & \\
\hline 9 & Open Spaces are protected & \\
\hline 10 & Industrial & \\
\hline 11 & Business & \\
\hline 12 & Facilities & \\
\hline 13 & Insulation facilities - non-fixed for development & \\
\hline 14 & Roads and highways in the buffer zone & \\
\hline 15 & Canals & \\
\hline
\end{tabular}

Table 3 Land Use of Amara City for 2007 and 2030 [14]

\begin{tabular}{|c|c|}
\hline 1 & Residential \\
\hline 2 & Mixed use \\
\hline 3 & Commercial and Institutional \\
\hline 4 & Industrial and Warehouses \\
\hline 5 & Education \\
\hline 6 & Health \\
\hline 7 & Administration and security \\
\hline 8 & Religious \\
\hline 9 & Cultural and tourism \\
\hline 10 & Open space/recreation/sports/youth/cemeteries \\
\hline 11 & Transportation and road network \\
\hline 12 & Public services \\
\hline
\end{tabular}


Table 4 Land Use of Hillah City for 2006 and 2030 [15]

\begin{tabular}{|c|c|}
\hline 1 & Residential \\
\hline 2 & Mixed use \\
\hline 3 & Commercial and Institutional \\
\hline 4 & Industrial \\
\hline 5 & Education \\
\hline 6 & Health \\
\hline 7 & Cultural and tourism \\
\hline 8 & Open space/recreation/sports/youth \\
\hline 9 & Religious \\
\hline 10 & Administration and security \\
\hline 11 & Infrastructure \\
\hline
\end{tabular}

Table 5 Land Use of Ramadi City for 2009 and 2033 [16]

\begin{tabular}{|c|c|c|}
\hline & 2009 & 2033 \\
\hline 1 & Residential & Residential \\
\hline 2 & Industrial & Industrial \\
\hline 3 & Commercial and Mix use & Commercial and Mix use \\
\hline 4 & Education & Education \\
\hline 5 & Religious & Religious \\
\hline 6 & Health & Health \\
\hline 7 & Public Buildings and services & Public Buildings and services \\
\hline 8 & Recreation & Recreation \\
\hline 9 & Green areas & Green areas \\
\hline 10 & Train station and railway & Train station and railway \\
\hline 11 & Water area & Water area \\
\hline 12 & Cemeteries & Cemeteries \\
\hline 13 & Transportation and roads network & Transportation and roads network \\
\hline 14 & Warehouse and oil stores & \\
\hline 15 & Military area & \\
\hline 16 & Special area & \\
\hline 17 & & Administrative centers \\
\hline 18 & & City center \\
\hline 19 & & District center \\
\hline 20 & & Quarter center \\
\hline 21 & & Neighborhood center \\
\hline 22 & & Cultural areas \\
\hline 23 & & Tourist investment \\
\hline 24 & & Car Showrooms \\
\hline 25 & & International transportation garage \\
\hline
\end{tabular}

Table 6 Land Use of Al Muqdadiya City for 2010 and 2030 [17]

\begin{tabular}{|c|c|c|}
\hline & 2010 & 2030 \\
\hline 1 & Residential & Residential \\
\hline 2 & Commercial & Industrial \\
\hline 3 & Industrial & Educational \\
\hline 4 & Educational & services \\
\hline 5 & Government administration and public services & Health \\
\hline 6 & Infrastructures & Religious \\
\hline 7 & Health & Tourism and Recreation \\
\hline 8 & Religious & Cultural \\
\hline 9 & Tourism and Recreation & Sports and Youth \\
\hline 10 & Cultural & \\
\hline 11 & heritage & Sports and Youth \\
\hline 12 & & \\
\hline
\end{tabular}




\begin{tabular}{|l|c|c|}
\hline 13 & Security & Transportation \\
\hline 14 & Transportation & Open space and green areas \\
\hline 15 & Open space and green areas & Agricultural areas \\
\hline 16 & Agricultural areas & Public services \\
\hline 17 & & Other land use \\
\hline 18 & & Energy \\
\hline 19 & & \\
\cline { 1 - 1 } & & \\
\cline { 3 - 3 } & &
\end{tabular}

Table 7 Land Use of Balad City for 2009 and 2035 [18]

\begin{tabular}{|c|c|c|}
\hline & 2009 & 2035 \\
\hline 1 & Residential & Residential \\
\hline 2 & & Mixed use \\
\hline 3 & Public Services & Recreational \\
\hline 4 & Recreational & Public places \\
\hline 5 & Public places & Transport infrastructures \\
\hline 6 & Transport infrastructures & Technical infrastructures \\
\hline 7 & Technical infrastructures & Industrial and production \\
\hline 8 & Industrial and production & Agricultural area \\
\hline 9 & Agricultural area & Water areas \\
\hline 10 & Parks, Lakes and landscape & Gardens and Orchards \\
\hline 11 & Water areas & Natural areas (swamps) \\
\hline 12 & & \\
\hline 13 & & \\
\cline { 2 - 3 }
\end{tabular}

Table 8 Land Use of Karbala City for 2007 and 2030 [19]

\begin{tabular}{|c|c|c|}
\hline & 2007 & 2030 \\
\hline 1 & $\begin{array}{c}\text { Residential (including streets in } \\
\text { neighborhoods and green squares) }\end{array}$ & $\begin{array}{c}\text { Residential (including streets in } \\
\text { neighborhoods and green squares) }\end{array}$ \\
\hline 2 & Industrial & Industrial \\
\hline 3 & Commercial & Warehouse \\
\hline 4 & Warehouse & Public services \\
\hline 5 & Educational & \\
\hline 6 & Health & Public facility (green and parking) \\
\hline 7 & Religious & Transport and roads \\
\hline 8 & Cemeteries & Agricultural area \\
\hline 9 & Public facility (green and parking) & Vacant area \\
\hline 10 & Transport and roads & \\
\hline 11 & Agricultural area & \\
\hline 12 & Vacant area & \\
\hline
\end{tabular}

Table 9 Proposed Classification of Land Uses for Iraqi Cities [Authors]

\begin{tabular}{|c|c|c|c|}
\hline & $\begin{array}{c}\text { Primary } \\
\text { Classification }\end{array}$ & $\begin{array}{r}\text { Secondary } \\
\text { Classification }\end{array}$ & Detailed Classification \\
\hline \multirow{6}{*}{1} & \multirow{6}{*}{$\begin{array}{l}\text { Residential } \\
\text { Land Use }\end{array}$} & \multirow{3}{*}{ Signal Unit } & Low - Density \\
\hline & & & Medium - Density \\
\hline & & & High - Density \\
\hline & & \multirow{3}{*}{$\begin{array}{l}\text { Multi-Story } \\
\text { Building }\end{array}$} & Low - Density \\
\hline & & & Medium - Density \\
\hline & & & High - Density \\
\hline \multirow{8}{*}{2} & \multirow{8}{*}{$\begin{array}{l}\text { Economic } \\
\text { Land Use }\end{array}$} & \multirow{3}{*}{ Commercial } & Wholesale \\
\hline & & & Retail \\
\hline & & & Stores and Warehouses \\
\hline & & \multirow{5}{*}{ Industrial } & Light Industries \\
\hline & & & Medium Industries \\
\hline & & & Heavy Industries \\
\hline & & & Car Service \\
\hline & & & Stores and Warehouses \\
\hline
\end{tabular}




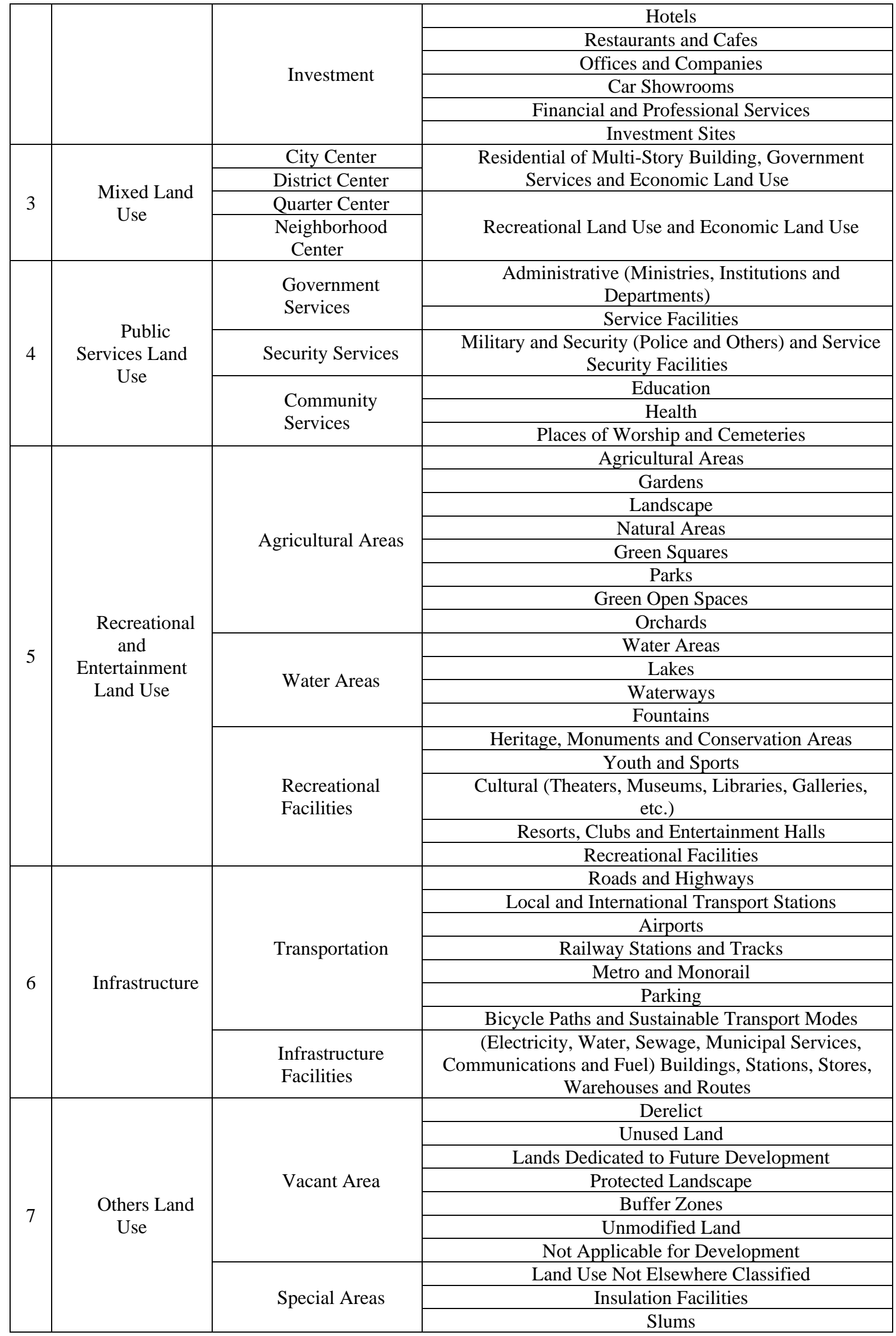




\section{Conclusion}

1) The city's function is important in classifying land uses in the city and is adding to the use of non-traditional land for classification according to its suitability for the city function.

2) There is no clear classification of the land uses in Iraqi cities either primary or secondary classification but there is a different classification of each city according to the existing of land use, and its adoption in whole or near total for future land uses, this is an indication of poor control over the distribution of land uses and their lack of consideration of technological developments and the spirit of the era characterized by the emergence of sustainable and environmentally friendly land uses, such as the mixed land use and the interest in sustainable transport modes

3) The process of integration of land uses converged randomly and unorganized in the classification of land uses in Iraqi cities.

\section{Recommendations}

1) Review the classification of land uses for the master plans of Iraqi cities and adopt the classification of land uses proposed in the research.

2) Taking into account the function of the city when classifying land uses to become it is most important land use in the preparation of master plans of the city.

3) Formation of a higher committee composed of government ministries (municipalities, housing and planning), specialists from university professors and experts in the field of land uses to prepare a new local guide that is compatible with the information and technological development, as a reference for all stakeholders in the field of master plans and land uses.

\section{References:}

[1] Khamas, Walid Mustafa, Naji, Hafeth I. \& Hasan, Aya A., Assessment and Optimization for Urban Planning Projects, Diyala Journal of Engineering Sciences, Vol. 11, No. 1, March 2018, p. 21.

[2] Hameed, Ali Hussein \& Al-kaissi, Zainab Ahmed, Future Predicted Dynamic Model Urban Growth For Baqubah City, Diyala Journal of Engineering Sciences, Vol. 8, No. 3, 2015, p. 157.

[3] Gong, Xiaoning \& Marklund, Lars Gunnar \& Tsuji, Sachiko, Land Use Classification Proposed to Be Used in the System of Integrated Environmental and Economic Accounting (SEEA)m Draft Version, FAO, 2009, p. 6.

[4] Holgu n-Veras, Jos; Jaller, Miguel; Sanchez-Diaz, Ivan; Wojtowicz, Jeffrey; Campbell, Shama; Levinson, Herbert; Lawson, Catherine; Powers, Erica Levine; and Tavasszy, Lorant, Freight Trip Generation and Land Use, National Academy of Sciences, Transportation Research Board, Washington, D.C., USA, 2012, p. 4.

[5] Nolon, J., P. Salkin and M. Gitelman, Cases and Materials on Land Use and Community Developmentm St. Paul, MN., Thomson/West, 2008, pp. 156-167.
[6] Mandelker, D., J. Payne, J. P. Salsich and N. Stroud, Planning and Control of Land Development: Case and Materials, Newark, NJ, 2008, pp. 852-886.

[7] Duerksen, C., Saving the World Through Zoning, Planning, 2008, 74(1): 28-33.

[8] Rutledge, Daniel \& Price, Robbie \& Briggs, Craig \& Cowell, Sarah, Geospatial Land-use Classification for New Zealand: Review and Recommendations, Official Statistics Research Series, Vol 5, Statistics New Zealand, Wellington, New Zealand, 2009, p. 9.

[9] Department of Rural Development and Land Reform, Report on the Workshops on Land Use Classification Standards, Methodology and Symbology, South Africa, 2013, pp. 21-22.

[10] Rutledge et al, ibid, 2009, p. 21.

[11] Harrison, RA., National Land Use Database: Land Use and Land Cover Classification, Version 4.4, United Kingdom Office of the Deputy Prime Minister, London, 2006.

[12] Ministry of Municipalities and Public Works, General Directorate of Physical Planning, Basra City Development Strategy and Update the Master Plan, Report of the sixth phase, chapter III, 2012, p. 8.

[13] Ministry of Municipalities and Public Works, General Directorate of Physical Planning, Basra City Development Strategy and Update the Master Plan, Report of the sixth phase, chapter VI, 2012, p. 1.

[14] Ministry of Municipalities and Public Works, General Directorate of Physical Planning, Amara Master Plan Update, Population and demographic characteristics Report, 2009, p. 3-7, 3-23 and 12-40.

[15] Ministry of Municipalities and Public Works, General Directorate of Physical Planningm Hillah Master Plan Update, Report of Phase VI, Chapter III, 2009, pp. 8 and 49.

[16] Ministry of Municipalities and Public Works, General Directorate of Physical Planning, Ramadi City Development Strategy and Update the Master Plan, Report of Phase V, Final Outline of the Master Plan, 2012, pp. 25, 26 and 172.

[17] Diyala Governorate, Directorate of Physical Planning, Al Muqdadiya City Development Strategy and Update the Master Plan, Report of Phase 5, 2013, p. 8, 35 and 84

[18] Ministry of Municipalities and Public Works, General Directorate of Physical Planning,Balad Master Plan Update, Report phase IV, chapter II, p. 26, chapter IV, p. 25 and chapter VI, 2007, p. 1.

[19] Ministry of Municipalities and Public Works, General Directorate of Physical Planning, Karbala Master Plan Upgrade, Setting and Evaluating Alternatives Stage Report, 2007, p. 2-5 and 5-26. 